\title{
Naboth's Vineyard: A guide for South Africa on the Vexing Land Issue
}

\author{
M. Z. Shamase and A. Nicolaides
}

\section{ABSTRACT}

The story of Naboth's vineyard (1 Kings 21:1-16) is one played out during the dynasty of Omri in Northern Israel (866-842 BCE) and speaks to an era in which socio-economics were largely dominated by political elites. The narrative concerns inter alia a clash between two arrangements of land ownership, inheritance and possession by others. Thus, from a socio analytical perspective, the story has lessons to impart to 2022 South Africa where the issue of the land redistribution is an important one given that even after a quarter of a century post-apartheid, millions of people continue to have no real access to land. Many people are thus left precariously exposed and vulnerable. The story imparts the truth that a leader of a state is bound to respect the proprietary rights of his citizens. In any event, viewed from a theological perspective, all the resources of creation are to be utilised to serve the common good and we are all custodians of creation. This includes people who have no private property of their own and who are for the most part excluded and side-lined by those in positions of power. The story of Naboth's vineyard is thus a simple one where a sovereign sees something he wants, and then formulates a strategy to get it. In Naboth's story, the king had him killed. This is a very constructive rendition of what happens when there's no justice and the dominant powers get to terminate those who stand in their way. Justice tends to break down when people lose perspective of who they are concerning God who ultimately forgives us when we atone.

Keywords: Fairness, Inheritance, Justice, Naboth, Proprietary Rights

Published Online: January 26, 2022

ISSN: $2736-5514$

DOI: $10.24018 /$ ejtheology.2022.2.1.58

\section{Z. Shamase}

Faculty of Arts, University of Zululand, South Africa.

(e-mail: shamasem ${ }^{@}$ unizulu.ac.za) A. Nicolaides*

Department of Philosophy and Applied Ethics, Faculty of Arts, University of Zululand, Kwa-Dlangezwa, South Africa.

http//:orcid .org/0000-0002-2153-2853

(e-mail: nicolaidesa@ unizulu.ac.za)

*Corresponding Author

\section{INTRODUCTION}

Abuses of power, including land grabs as blatant as Ahab's in the Old Testament, continue today, as is evidenced in daily media reports. The context of the story is important for us to unpack briefly. In the 9th century BCE, the Kingdom of Israel, which was once united under King Solomon, became divided into the northern Kingdom of Israel and the southern Kingdom of Judah which kept the capital of Jerusalem. Omri, King of Israel, followed policies that diverged with Mosaic law, and these sought to reorientate religious emphasis away from Jerusalem and they encouraged the construction of local temple altars for sacrifices, and they even appointed priests from outside the family of the Levites (Raven, J1979). Critically, they allowed temples to be constructed that were dedicated to Baal and also Asherah (Kaufman, 1956). Omri cemented his domestic security through the marriage and thus forged an alliance between his son Ahab and Jezebel, a princess from Phoenicia and a worshipper of Baal. She was the daughter of the king of Sidon in Phoenicia. The marriage was aimed at providing Israel with a measure of security. In this state of affairs, Naboth a Tishbite, possessed a vineyard, near King Ahab's palace in Jezreel and the king wished to obtain the vineyard in order to create a vegetable garden for himself (Dospěl, 2017).

King Ahab clearly abused his authority once he began to crave ownership of the vineyard of Naboth who was after all, his neighbour. Ahab proposed what he considered to be a fair price for his vineyard, but Naboth considered the land to be a patrimonial space and a familial bequest and thus avers that he has no intention of selling it to anyone at any price (Amit, 2019). We should also note that in terms of Mosaic law, Canaan was considered to be God's land and His alone (Na'aman, 2008). The Israelites thus viewed themselves as being mere tenants. An important condition of their tenure was that they should not separate that which fell to their lot except when there was some necessity, and even then they could only do so until the year of Jubilee (Russell, S2016). There were extenuating circumstances such as, for example, when one couldn't pay his debts, he could sell his land. The Year of Jubilee ("Yovel" in Hebrew) was ordered every 50th year (seven weeks of seven years, which total 49 years). We read in Leviticus: "Proclaim liberty throughout the land to all its inhabitants. It shall be a jubilee for you, when each of you shall return to his property and each of you shall return to his clan" (25:10).

We could argue that Naboth does not accept Ahab's offer for various reasons. Firstly, cultivating a vineyard is time consuming, and secondly it is somewhat costly and a painstaking process (Vandagriff, 
2019). In any event, Naboth's family had passed the land down for numerous generations ( ', אמית \& Amit, 2015). He was not desirous of getting rid of it and possibly wished to pass it down to his children. Critically, he likely comprehended that the land on which his family lived linked him to something larger than himself (Russell, 2014; Brueggemann, 2021). In any event, as stated by Mosaic law, it was forbidden to permanently sell land (Andersen, 1966; Kaiser, 2012). In any event the scriptures are clear that the land is God-given: "Go from your country and your kindred and your father's house to the land I will show you." (Genesis 12:1), "To your descendants I give this land, from the river of Egypt to the great river, the Euphrates, the land of the Kenites, the Kenizzites, the Kadmonites, the Hittites, the Perizzites, the Raphaim, the Amorites, the Canaanites, and Girgashites, and the Jebusites." (Genesis 15:18-21) and also "And I will give to you, and to your offspring after you, the land where you are now an alien, all the land of Canaan, for a perpetual holding; and I will be their God." (Genesis 17:8).

In premodern land-tenure systems, vineyards belonged to the category of private property. Unlike fields and pastures, they required major investments in physical and material resources. Naboth as the owner could sell his vineyard if he desired to do so. The fact that he had inherited the vineyard from his fathers was no legal impediment to the sale. "His vineyard being under the jurisdiction of the Assyrian governor of Megiddo, Naboth considered the king of Samaria a ruler who could be snubbed; he underestimated the power of Jezebel, however!" (Guillaume, n.d.).

Ahab disappointedly accepts this fitting limitation of his authority and power in society. Unfulfilled at his failure to acquire the vineyard, he returned to the palace and went to bed without eating anything. His wife, Jezebel, after ascertaining the cause of his unhappy state, contemptuously derides him by stating, "Do you now govern Israel?" (1 Kings 21:7).

We read in Kings 21: 1-28 the story:

21: Sometime later there was an incident involving a vineyard belonging to Naboth the Jezreelite. The vineyard was in Jezreel, close to the palace of Ahab king of Samaria. 2 Ahab said to Naboth, "Let me have your vineyard to use for a vegetable garden, since it is close to my palace. In exchange I will give you a better vineyard or, if you prefer, I will pay you whatever it is worth."

3: But Naboth replied, "The LORD forbid that I should give you the inheritance of my ancestors."

4: So Ahab went home, sullen and angry because Naboth the Jezreelite had said, "I will not give you the inheritance of my ancestors." He lay on his bed sulking and refused to eat.

5: His wife Jezebel came in and asked him, "Why are you so sullen? Why won't you eat?"

6: He answered her, "Because I said to Naboth the Jezreelite, 'Sell me your vineyard; or if you prefer, I will give you another vineyard in its place.' But he said, 'I will not give you my vineyard.'”

7: Jezebel his wife said, "Is this how you act as king over Israel? Get up and eat! Cheer up. I'll get you the vineyard of Naboth the Jezreelite."

8: So she wrote letters in Ahab's name, placed his seal on them, and sent them to the elders and nobles who lived in Naboth's city with him. 9 In those letters she wrote:

"Proclaim a day of fasting and seat Naboth in a prominent place among the people. 10 But seat two scoundrels opposite him and have them bring charges that he has cursed both God and the king. Then take him out and stone him to death."

11: So the elders and nobles who lived in Naboth's city did as Jezebel directed in the letters she had written to them. 12 They proclaimed a fast and seated Naboth in a prominent place among the people. 13 Then two scoundrels came and sat opposite him and brought charges against Naboth before the people, saying, "Naboth has cursed both God and the king." So they took him outside the city and stoned him to death. 14 Then they sent word to Jezebel: "Naboth has been stoned to death."

15: As soon as Jezebel heard that Naboth had been stoned to death, she said to Ahab, "Get up and take possession of the vineyard of Naboth the Jezreelite that he refused to sell you. He is no longer alive, but dead." 16 When Ahab heard that Naboth was dead, he got up and went down to take possession of Naboth's vineyard.

17: Then the word of the LORD came to Elijah the Tishbite: 18: "Go down to meet Ahab king of Israel, who rules in Samaria. He is now in Naboth's vineyard, where he has gone to take possession of it. 19: Say to him, 'This is what the LORD says: Have you not murdered a man and seized his property?' Then say to him, 'This is what the LORD says: In the place where dogs licked up Naboth's blood, dogs will lick up your blood-yes, yours!"”

20: Ahab said to Elijah, "So you have found me, my enemy!"

"I have found you," he answered, "because you have sold yourself to do evil in the eyes of the LORD.

21: He says, "I am going to bring disaster on you. I will wipe out your descendants and cut off from Ahab every last male in Israel—slave or free.[a] 22: I will make your house like that of Jeroboam son of Nebat and that of Baasha son of Ahijah, because you have aroused my anger and have caused Israel to sin.'

23: “And also concerning Jezebel the LORD says: 'Dogs will devour Jezebel by the wall of[b] Jezreel.' 
24: "Dogs will eat those belonging to Ahab who die in the city, and the birds will feed on those who die in the country."

25: (There was never anyone like Ahab, who sold himself to do evil in the eyes of the LORD, urged on by Jezebel his wife. 26: He behaved in the vilest manner by going after idols, like the Amorites the LORD drove out before Israel.)

27: When Ahab heard these words, he tore his clothes, put on sackcloth and fasted. He lay in sackcloth and went around meekly.

28: Then the word of the LORD came to Elijah the Tishbite: 29: "Have you noticed how Ahab has humbled himself before me? Because he has humbled himself, I will not bring this disaster in his day, but I will bring it on his house in the days of his son.” (1 Kings 21 - New International Version).

In Jezebel's estimation, Naboth's attitude and response are one of gross insubordination. She this had no compunction in dealing with him. Jezebel thus states that she will obtain the vineyard for him. The plot thickens as she sends a letter, falsely using Ahab's name, to the elders and nobles of Naboth's city. They are instructed to frame Naboth by announcing a fast and they instruct Naboth to be seated in a "prominent place." Jezebel compensates two villains, Jehu and Bidkar (2 Kings 9:25), to bring false charges of alleged blasphemy, cursing the monarch and treason against Naboth for supposedly cursing God and also King Ahab.

Naboth was then arraigned before his peers in Jezreel and falsely accused and subsequently charged and killed. There is no doubt that Jezebel had enough power to make the elders and nobles conspire with her. Even though Ahab reportedly tore his clothes and wore sackcloth, he was still party to a despicable crime. Once the elders are deceived by the villains, Naboth is sentenced to death by stoning beyond the city walls, since the accusations leveled against him according to Deuteronomy 17:6 and 19:15, are adequate to charge a guilty suspect accused of committing offenses that were deemed to be worthy of the death penalty.

Ahab must surely have connived in the acts which followed and in allowing the use of his name and of the royal seal in the letter which Jezebel sent to the city elders and nobles stating the celebration of a fast. The story of Naboth's vineyard is a powerful witness to the relevance of God in all socio-economic issues.

Hirsch and Seligsohn (1902) argues: "It seems from II Kings ix. 26 that Naboth's sons perished with their father, probably being killed soon afterward by order of Jezebel in order that they might not claim the vineyard as their inheritance". Once Naboth was executed, Jezebel instructed Ahab to take over the tenure of the vineyard. Thus an inherited inheritance was taken from its lawful owner and transferred to King Ahab. The prophet Elijah, leveled a verbal tirade against Ahab and then foretold disaster for Ahab's dynasty and the ignominious death of Ahab and also Jezebel (1 Kings 21; Farisani, 2005) and thus the annihilation of the Omride dynasty. Naboth was the only one audacious enough to oppose Ahab (1 Kings 21:17-24) and to stand for justice. The story communicates to us the very important message, namely, that a monarch is duty bound to respect the proprietary rights of others (Andersen, 1966). Ahab through his misguided actions undoubtedly contravened both Deuteronomy 15:1-11 and also 17:14-20 (Scheffler, 2017). He and Jezebel ceased to be moral agents and became instruments of death through avarice and clearly did not adhere to Mosaic law stipulations:

15: "At the end of every seven years you shall grant a release of debts. 2 And this is the form of the release: Every creditor who has lent anything to his neighbour shall release it; he shall not require it of his neighbour or his brother, because it is called the Lord's release. 3....For the poor will never cease from the land; therefore I command you, saying, 'You shall open your hand wide to your brother, to your poor and your needy, in your land" (Deuteronomy 15:1-11)

And,

15: ...you shall surely set a king over you whom the Lord your God chooses; one from among your brethren you shall set as king over you; you may not set a foreigner over you, who is not your brother...17: Neither shall he multiply wives for himself, lest his heart turn away; nor shall he greatly multiply silver and gold for himself. 18: "Also it shall be, when he sits on the throne of his kingdom, that he shall write for himself a copy of this law in a book, from the one before the priests, the Levites. 19: And it shall be with him, and he shall read it all the days of his life, that he may learn to fear the Lord his God and be careful to observe all the words of this law and these statutes, 20: that his heart may not be lifted above his brethren, that he may not turn aside from the commandment to the right hand or to the left, and that he may prolong his days in his kingdom, he and his children in the midst of Israel. (Deuteronomy 17:14-20)

Ahab also acted in accordance with Samuel's prophecy in 1 Samuel 8:10-17. 
10: So Samuel told all the words of the Lord to the people who asked him for a king. 11: And he said, "This will be the behavior of the king who will reign over you: He will take your sons and appoint them for his own chariots and to be his horsemen, and some will run before his chariots. 12: He will appoint captains over his thousands and captains over his fifties, will set some to plow his ground and reap his harvest, and some to make his weapons of war and equipment for his chariots. 13: He will take your daughters to be perfumers, cooks, and bakers. 14: And he will take the best of your fields, your vineyards, and your olive groves, and give them to his servants. 15: He will take a tenth of your grain and your vintage, and give it to his officers and servants. 16: And he will take your male servants, your female servants, your finest [a]young men, and your donkeys, and put them to his work. 17: He will take a tenth of your sheep. And you will be his servants.

In chapter 21 of the Book of 1 Kings, the first thing that strikes us is the crime perpetrated by Ahab. While Jezebel promoted the crime, Ahab was ultimately responsible for what he allowed to come to transpire. Elijah asks Ahab, "Hast thou killed and also taken possession?'” So while it was Jezebel who carried out the reprehensible conspiracy, it is Ahab who is responsible, since he is the man in the family in a paternalistic era, and he is, of course, the King of Israel. (Yafé, 1989). Ahab's bargaining was contrary to the law of God, which he, as the supreme ruler in the land was accountable for maintaining. The story speaks to the notion of autocratic interference with the rights of a simple citizen in God's land. The property belonged to God, and Ahab desired it and he forgot that true happiness consists in one having possession of Godly graces, and being fully satisfied with what God gives one whether in eighth-century Israel or today. Psalm 24:1 teaches us, "The earth is the Lord's, and the fulness thereof; The world, and they that dwell therein".

Magdalene (2014) informs us that “... in the Hebrew Bible, YHWH and, at times, the whole Divine Council would intervene in these situations and try the case in the divine courtroom in order to maintain justice. Often a royal prophet would accuse the king as YHWH's or the Council's agent. In other instances, the prophet would announce the heavenly verdict to the king. The incident concerning Naboth's vineyard which is found primarily in 1 Kings 21 but is also discussed in 1 Kings 22 and 2 Kings 9 -10, is one of the key texts."

The most important lesson of Naboth's vineyard is that there is ultimately only one type of injustice and Ahab's iniquities come down to a singular issue of injustice in that he fails to honour God and loses sight of God as a God who is just. Having said that, the biblical narrative as not merely about a case of an abuse of power, but also speaks to complicity by agents and economic considerations concerning land issues. Naboth was an innocent man and a victim of greed and he was powerless to stand against Ahab and none of the people in his village stood up for him. There were definitely no checks and balances, or room for any type of appeal to be made. We can only but surmise why the elders, who are complicit in the crime acted so speedily and did not even bother to conduct a fair trial. Elijah advocated a strict Deuteronomic interpretation of the Mosaic law and his opposition did finally curb Ahab's abuse of his power, and no more abuses are noted for our information in Kings up to when Ahab dies. Elijah's dramatic arrival in the story demonstrates that the problem between Naboth and Ahab is not only an economic one. It is in essence a theological and power abuse argument.

When people attempt to commodify creation, they voluntarily or even involuntarily contribute to its demise. However, Creation is God given and received by people who are its custodians. We are called to rather be "submitting to one another in the fear of God" (Ephesians 5:21) and seek self-aggrandisement. Moses advised on some of God's wishes: "Thou shalt not covet thy neighbour's house, thou shalt not covet thy neighbour's wife, nor his man-servant, nor his maid-servant, nor his ox, nor his donkey, nor anything that is thy neighbour's" (Exodus 20:17). Ahab was not attentive. The message of the story also manifests as a complaint of the oppressed against the upper classes. In addition, Jezebel, is a Canaanite, a sinner and seducer, and she is the foreign wife of Ahab and through her and her vile actions, foreign women in general are stigmatised (Rofé, 1988). It is also a tale of kingship, citizenship, and of property (Akulli, 2011).

Ahab eventually has to reckon with an Elijah and his conscience, "And Ahab said to Elijah, Hast thou found me, O mine enemy?" (1 Kings 21:20). King Ahab thus calls Elijah his enemy and the prophet retorts by throwing the charges back at him, and by expressing the view that Ahab has made himself the enemy of God by his own actions. Elijah states that Ahab will be rejected in kingdom and that he will lose his authority. Elijah also states that Jezebel will be consumed by dogs in Jezreel; and that Ahab's 'house' will also be consumed by either dogs or by birds. Ahab immediately repents so that God yields in punishing Ahab totally, but punishes Jezebel and their son Ahaziah. Elijah's prophecy is fulfilled when Jehu executed Ahab's son Jehoram by shooting him in the back with an arrow, and then his corpse was thrown into the field of Naboth the Jezreelite, as punishment for his parents' iniquity in plotting and planning the illegal stealing of Naboth's land. Jezebel was also thrown off a building, and her corpse was consumed by dogs. When they went to inter her, they only found her skull and the feet and the palms of her hands. When Elijah was informed of the finding he retorted, "This is the word of the Lord, which he spoke by his servant Elijah 
the Tishbite, 'In the territory of Jezreel the dogs shall eat the flesh of Jezebel; the corpse of Jezebel shall be like dung on the field in the territory of Jezreel, so that no can say, This is Jezebel" (II Kings 9:35-37). Whatever Elijah foretold finally transpired. Ahab partially repented, but sadly returned to his evil ways. He was wounded by an arrow fired at him, "....and the blood ran out of the wound into the midst of the chariot..." (1 Kings 22:35) and as they washed his chariot in a fountain in Samaria, dogs licked his blood - thus fulfilling the prediction of Elijah, Yahweh's prophet who was Jezebel's nemesis. Later, when Jehu sent people out see, there was nothing of Jezebel left for interment and the corpse of their son Joram was also left unburied on that same plot, at the command of Jehu. God is a God of love but also a God of wrath and his is true to His promises.

While Naboth's life could not be restored, justice manifests itself but more importantly repentance, forgiveness and reconciliation. Ahab abused his position of authority and used it to acquire what wanted through greed, by force. Baal was the god of commoditization in which all and sundry and "...everything can be bought and sold, used, traded and disposed of, without worth or value beyond its usefulness." (Brueggemann, 2021). By accepting Baal worship and suchlike, Israel was demonstrating its straying from the true God and pacing itself on a trajectory to destruction. Wickedness does not pay no matter how fruitful it seems at first.

No person will have any exemption for the manipulative pursuit of land or its "inheritors!". We read "11 But the meek shall inherit the earth; and shall delight themselves in the abundance of peace. 12 The wicked plotteth against the just, and gnasheth upon him with his teeth. 13 The Lord shall laugh at him: for he seeth that his day is coming" (Psalm 37:11-13). Also in Matthew 5:5 we find "5 Blessed are the meek: for they shall inherit the earth."

God envisioned the earth with all in it for the use of all peoples. Consequently, we need to be cognisant of the fact that all we possess is also common in the sense that what we have should also be able to benefit us and also others with whom we interact. (Whelan, 66) In fact, Naboth is the first of many "martyrs of corruption" (Pani, 2018).

Ahab and Naboth, the protagonists in the vineyard case, are paradigmatic characters from the history of South Africa and many other places, where authority becomes arrogant, and justice is corrupted by unscrupulous people in positions of power. They pillage and plunder at the expense of the poor and downtrodden (Pani, 2018). Paradoxically it is some of the wealthy in society who are needier than the poor, since they are blinded by egoism and are utterly narcissistic and, of course, are never satisfied with their immense wealth, always craving more. They oppress their fellow human beings and lack any sense of solidarity with them, mindful only of the present and unconcerned about God's judgement. The opulence of the wealthy is often forged on the misery of the poor. Those who covet their neighbours goods are often disquieted by their cravings and are never content, so enough is never enough. They should rather be generous to the poor and serve in a Christlike manner given that we are made in the imageo Dei. Contrarily, while Ahab did not generate the breakdown of the State economy, he was the root cause for the collapse a family economy, "...for example, the murder of Naboth that exposed his family to poverty and hardship since the State took over the land which was the basis and source of family livelihood" (Gora, 2008).

Riches are indeed a gift from God and should also be used to support the needy in society. Ahab and Jezebel both defied the Lord, but they could not get away with their injustice. God acted against them since God is the one with whom all people have to deal and before whom all men and women will stand to give an account of themselves (Romans 14:12). 1 Kings 21:1-29, relates that Ahab was exonerated by God, but there is no mention if Ahab in fact returned the land to the family of Naboth. In the world today as always, there are two distinct groups of people. Some are like Ahab and Jezebel, and then there are others like Naboth and Elijah. In Matthew 7:13-14: "13 Enter by the narrow gate; for wide is the gate and broad is the way that leads to destruction, and there are many who go in by it. 14 Because narrow is the gate and difficult is the way which leads to life, and there are few who find it" and Proverbs 4:18-19. 1: "But the path of the just is like the shining sun, That shines ever brighter unto the perfect day.19 The way of the wicked is like darkness; They do not know what makes them stumble" it is evident that God will yet vindicate His people, the 'nation of God' (Laos tou Theou) (see Nicolaides, 2010; 2011). Ahab, who through his marriage to Jezebel allowed to Baal worship in Israel and he is thus a monarch who made Israel sin.

During Ahab's reign there was an additional shift away from the egalitarian land ideology that safeguarded almost equal access to resources, especially land among the Israelites to a 'tributary socio-economy' in which the civil liberties of the ruling class were given first preference (Gora, 2008). The Naboth narrative validates an archetypal move and departure by the ruling class from the traditional social structure to a situation in which the monarch had advantages over the peasants. Ahab could not force the sale of the land and this alludes to a situation where the state and peasants were at odds for years (Farisani, 2005). Elijah found the situation to be deteriorating rapidly, and had warned the people earlier of injustices occurring, hence his intervention as a man of God seeking justice for the downtrodden. A system that supported class divisions was rapidly coming into being in Israel (Gora, 2008; West, 1999). Ultimately, 
"the Israelite peasants expected the return of the egalitarian socio-economic order in which all had access to resources, especially land. For example, the family of Naboth that had lost their land during the reign of Ahab, anticipated land restitution as soon as the reign of Ahab came to an end. For the Israelites, the Jehu revolution was an opening into a new social order" (Gora, 2008). God will and does certainly impose judgment on people like Ahab and Jezebel who are rebellious against Him, and reject His word, and especially those who fail to humble themselves before Him.

\section{LAND ISSUE AND THE NEW DEMOCRATIC DiSPENSATION IN SOUTH AFRICA}

The breakdown of apartheid-era land distribution and occupancy took place between 1990 and 1994. The apartheid system had already divided South Africa into 11 areas by that time. To the elite racial groups, this was Greater South Africa, which included the four "autonomous" nations of Transkei, Bophuthatswana, Venda, and Ciskei, as well as the six Self-Governing Territories of Gazankulu, KwaZulu, Kangwane, KwaNdebele, Lebowa, and QwaQwa. The enormous, but unusual rural areas reserved for Black people according to their race or ethnicity were referred to as Bantustans, or independent states and self-governing territories.

By pushing the Abolition of Racially Based Land Measures Act, the De Klerk government contributed to the end of apartheid (1991). This piece of legislation orbited infamous land denial statutes like the Land Acts (1913 and 1936) and Group Areas Act (1966). Non-Whites have been deprived of their aboriginal rights to land throughout the country's history due to colonization, segregation, and apartheid.

This land was intended for the restoration of white colonies or was kept as state land until 1991. As a result of this long period of discrimination, only $20 \%$ of the population owned 87 percent of the world. Before any land reform could be considered, an ongoing land reform process had to be instituted to address the past evictions. This was never an easy task, and a critical measurement measure followed between the various nations (Hodson 1996).

In 1991, the Land Redistribution Commission was established to deal with restitution in respect of state land, and in 1993, it was mandated to issue specific directives. In 1994, the national unity government faced the daunting task of passing a Restitution of Land Rights Act (November 1994). The purpose of the bill was to repeal previously discriminatory land laws. As a result, in 1996, the Land Claims Court was established, together with the Commission, to deal with "any claims arising from state action since the application of the Indigenous Land Act of 1913." (Christopher 1995).

The Court that deals with land claims is a court dedicated to resolving issues arising from the legislation that govern South Africa's land reform project. The Restitution of Land Rights Act (1994), the Land Reform (Labour Tenants) Act (1996), and the Extension of Security of Tenure Act are examples of land-related legislation (1997). The Land Claims Court has practically the same legal authority as the Supreme Court.

The Constitutional Court hears the appeals. The claimants' remedies include:

- an order of restoration when possible;

- a decision of compensation when restoration is not possible;

- where possible, the award of an acceptable right in accessible state or public land, as well as any other

These remedies were supposed to result in land acquisition. Despite the fact that the deadline was met in 1998, only $90 \%$ of the land claims were investigated or settled. In 2013, the South African government intended to revive the land claims process. On February 24, 2013, Gugile Nkwinti, Minister of Rural Development and Land Reform, informed The New Age newspaper and the wider media:

"The agency wants to reopen the system so that anyone who missed the first deadline a few years ago can participate... There were still questions about who controlled the private property... it's unclear how many people from each race group own land."

On August 14th, the Minister resumed the land claims procedure in East London, Eastern Cape, after the signing into law of the Restitution of Land Rights Amendment Act last month. In 1998, the front window shuttered, leaving many community applications unfinished (SAPA Press Release).

\section{A. Current Scenario: A Political Imbroglio}

There's no denying that the land question is a sensitive one. In South Africa, discussions on land have grown emotional and sensitive. In the end, land was and continues to be a major source of strife in South Africa. The sentiments of people who have been hurt by the slow pace of land reform are expressed in the following excerpt:

The rural poor and urban unemployed in South Africa continue to talk about their need for land.

Many people who live in cities and don't have access to protected land have experienced this (or even semi-urban farm land). 
Those who live on community land have claimed that there isn't enough acreage for the amount of people who live there.

As a result of new labor and land regulations enacted (ironically) to protect their rights, farm laborers and labor tenants are increasingly facing eviction.

For the long-term unemployed and those without formal employment, access to property is sometimes a final resort.

This organization is worried about the slow pace with which restitution claims are resolved and the limited number of land redistribution schemes available (Anseeuw \& Alden 2011:36-37).

The 'willing buyer/willing seller' method has had a negative impact on the speed of (land) restitution.," said South Africa's then-Deputy President in 2005. (Anseeuw \& Alden 2011:28). The ill-fated GEAR Policy, which ran from 1999 to 2004, ensued that Land reform is a priority. The promotion of subsistence farming was essentially halted in favor of the development of a flourishing commercial farming industry.

Land reform was no longer focused on distributing land to African-Americans in order to foster selfsufficiency. Instead, land reform spawned and nurtured a slew of well-organized small-scale commercial farming operations. The idea was to increase farm productivity while also regenerating the rural landscape and creating jobs. As one might expect, "the impact of this change in government policy was notably visible in the land redistribution and land tenure reform programs." (Anseeuw \& Alden 2011:30).

The African National Congress (ANC) and the Economic Freedom Fighters (EFF) had different reactions when President Jacob Zuma signed the restitution of land rights amendment bill and the property value bill into law on June 30, 2014. The ANC hailed this as a win for millions of South Africans who had lost their land due to prejudice in the past. Zizi Kodwa, their spokeswoman, praised it as a "strong and decisive gesture that demonstrates the people of South Africa's urgency for comprehensive land reform" (Kodwa 2014). This strategy, according to the EFF, is unethical and expensive since it distorts the history of land theft and continues to divide people into ethnic groups rather than ensuring equal distribution.

On September 5, 2014, Jaco Oelofse, the leader of their University of Pretoria student command team, claimed at the South African Press Association (SAPA) that "The land belongs to us. No compensation should be paid; the property should be returned to its original owners" (Oelofse 2014). This graphic depicts the struggle for land in South Africa between the government and radical politics (revolutionaries). There is a narrow line between the proponents of justice and the victims of the same justice. Caution and radicalism are diametrically opposed. Ideological squabbles stymie the process. The masses who have been victimized are the ones who bear the brunt of power politics. The disconnected involvement has become the standard in today's politics.

The issue remains: who will emerge victorious in this land war? The land claims procedure has now begun, and it will be fascinating to see it unfold. Finally, the current administration is in charge of Ahab's greed problem management (the past colonial and apartheid regimes). His wife, Jezebel (radical politicians whose vanity is to invent some disruptive laws), is on a mission to accuse the dispossessed of treason and murder. Since losing what gave them significance, Naboth-like land grab victims are dying of starvation, shame, and disdain. It takes time for them to receive justice.

\section{B. South African Land Issue: Ecclesiastical Lessons}

Many individuals in South Africa have been displaced as a result of land policy, leaving them without a sustainable source of income. The vast majority of the population was exiled to arid and inhospitable lands (Bantustans). There was no considerable industrial growth in these locations. White minorities received 87 percent of the land, while the Black majority received 13 percent.

The scenario of Micah's day, in which the social elite occupied significant positions of authority, was replicated in South Africa from the introduction of the Glen Grey Act (1894) to the Land Act (1994). (1936). The spirit of Ahab reigned supreme over the administration of the day. The colonial aristocracy amassed huge tracts of land at the expense of indigenous peoples who were powerless, disenfranchised, and disadvantaged. Land greed took precedence over or ignored the property rights of the poor.

Just like the political authorities of eighth-century Israel, Engelbrecht et al. (1987:52) concur that they misused their positions of authority for the profit of economic interests. The majority of the populace had their inheritance stolen from them. To make them landless destitute, they were stripped of their dignity and significance in life. So-called Western civilization and progress undermined people's property rights, just as they did in the days of Omri and Ahab.

The dispossessed said, "The Lord forbid that I should relinquish the estate of my fathers to you," and were forcibly taken and placed in the designated locations. They had their dignity, civil rights, and respect taken away from them. According to the definition, someone who loses them "in fact loses his human dignity and is bereft of independence and self-reliance." His life is in the hands of others from that moment forward, who can use or mistreat him as they see fit" (Engelbrecht et al. 1987:53). Apartheid legislation has been repealed in its entirety. 
The ruling elite's flaw at the time was their contempt for a coherent social justice theology. In their economic sphere, which is land, they exploited lawful citizens. Micah 2:1-2 informs the reader that they planned schemes to exploit the bulk of the impoverished to their benefit. Both economic and social privilege were gained via the use of political power and status. Land was illegally taken in order to enrich the ruling class of the time.

\section{CONCLUSION}

Use either SI (MKS) or CGS as primary units. (SI units are strongly encouraged.) English units may be

Theologically, the objective is essentially to return to the biblical land exposition. The willingness or voluntary steps toward land restoration should be at the top of the list. Self-examination goes hand in hand with restoration. Human wickedness and its dreadful consequences are all-encompassing. Both the criminal and the victim must acknowledge their inability to redeem themselves. They must both accept historical injustice and engage in Christ-like dialogue that will lead to a shared understanding of the property transaction.

It is impossible to hang on to something that has been restored. On the other hand, one cannot succumb to despair or a victim attitude. In theological circles, there is a lot of talk about the land. An amicable conclusion should be reached through dialogue. Keep in mind the negotiation's strength.

'God chose language as a means of conveying power... Words are employed to bring harmony - or discord - among ourselves and among others. The 'word' is the fulcrum of history, both personal and worldwide.' (Berghoef \& Dekoster 1984:149).

All the extremes of political and ecclesiastical ideologies must hold to canonical truth as hermeneutically understood in Naboth's vineyard narrative. All ideologies must be scrutinized by the exegetical and hermeneutical truth extracted from this narrative. The authentic liberation is based on this truth:

Truth, not dogma, is what matters! Truth, not ideology, is the one who creates! Truth, rather than ideology, finds constructive expression in social justice and progressive practice (Berghoef \& Dekoster 1984:127-129).

The victims appear to be unsatisfied by the land arguments that take place in the halls of authority. Incomplete justice is the same as justice denied. Scriptures (Elijah's prophetic role to Ahab's administration) demand ecclesiastical groups to collaborate in order to expedite land restoration in South Africa. It is suggested that the land-restoration debate be avoided in order to prevent South Africa from becoming a totalitarian state that supports oppressive institutions that are so brutal, un-liberating, and antihuman that realpolitik (power politics) cannot be reconciled with vox populi (voices of the masses).

Theological orthodoxy (sound opinion based on canonical norm) must be properly balanced with heterodoxy (expression of human opinion ungoverned by canonical standards). As difficult as it may appear, the constant debate is a means of reaching symphony in terms of land allocation. True, "Words lead praxis and weave the fabric of history" (Berghoef \& Dekoster 1984:129).

Restoration is referred to as renewal, revival, re-establishment, restitution, renovation, reconstruction, or reproduction. It's all about regaining one's old standing or reclaiming one's lost respect. Land restoration theology is based on restorative justice, which promotes peace and prosperity. The accessibility and utilization of the land determine the land's success. This can be realized through a symbiotic interaction between government and religious formations. After that, justice and shalom will kiss each other (Lampman \& Shattuck 1999:113).

As a result, the ecclesiastical communities have conclusively justified grounds to return to the canonical mission of restorative justice. The land debate must continue in order to achieve justice and socio-economic progress on the path to peace, prosperity, and patriotism.

\section{CONFLICT OF INTEREST}

Authors declare that they do not have any conflict of interest. 
European Journal of Theology and Philosophy www.ej-theology.org

\section{REFERENCES}

Akulli, K. (2011). More than just Naboth's vineyard reflections on the implications of the community on exploitation and corruption in the context of I Kings 21, Kairos: Evangelical Journal of Theology, 5(2), 291-305.

Amit, Y. (2015). Shaping and Meaning in the Story of Naboth's Vineyard (1 Kgs 21), Beit Mikra: Journal for the Study of the Bible and Its World, Jerusalem: B ialik Institute. 36-19): $\aleph(\mathrm{O}$. [Available online at http://www.jstor.org/stable/24430215]

Amit, Y. (2019). Formation and Significance in the Story of Naboth's Vineyard (1 Kgs 21), Ben Porat Yosef, pp. 229-242.

Andersen, F. I. (1966). The Socio-Juridical Background of the Naboth Incident, Journal of Biblical Literature, 85(1), 46-57.

Anseeuw, W. \& Alden, C. (2011). From freedom charter to cautious land reform: The politics of land in South Africa. Discussion Paper No. 2011/1. Postgraduate School of Agriculture and Rural Development, University of Pretoria.

Berghoef, G. \& Dekoster, 1. (1984). Liberation theology: The church's future shock. Grand Rapids, MI: Christian Library Press.

Brueggemann, W. (2021). What Naboth Teaches Us Today Part I \&II, Church Anew. [Available online at https://churchanew.org/brueggemann/what-naboth-teaches-us-today-part-i] January 22, 2021.

Calvo, J. (2000). Naboth's vineyard, Acta Académica, 27, 46-60.

Christopher, A.J. (1995). Land restitution in South Africa, 1991-94, Land Use Policy, 12(4), 247-279.

Dospěl, M. (2017). Naboth's Vineyard Unearthed at Tel Jezreel?, Bible History Daily, Biblical Archaeology Society, November 6, 2017.

Engelbrecht, J., Van Dyk, P.J., Sebothoma, W.A. \& Strydom, J.G. (1987). On creation and re-creation. Themes from the Bible: Creation, justice, faith, and the church. Pretoria: Van Schaik.

Farisani, E. B. (2005). A sociological reading of the confrontation between Ahab and Elijah in 1 Kings 21: 1-29, Old Testament Essays, 18(1), 47-60.

Hirsch, E.G. \& Seligsohn, M. (1902). Naboth, Jewish Encyclopedia, Funk \& Wagnall Vol IX Morawczyk Philippson.

Hodson, T. A. (1996). South African land tenure, past and present: A country report. Department of Spatial Information, Science, and Engineering. University of Maine.

Kaiser, W. C., Jr. (2012). Ownership and property in the Old Testament economy, Journal of Markets \& Morality, 15(1).

Kaufman, Y. (1956). The Biblical Age, In Schwarz, Leo W. (Ed.). Great Ages and Ideas of the Jewish People ( pp. 53-56). New York, NY: Modern Library

Kodwa, Z. (2014). Mixedreactoin ti landbill. [Available online at http://www.news24.com/ SouthAfrica/Politics/Mixed-reaction-toland-bill-20140701]

Lampman, 1. B. \& Shattuck, M. D (eds.) (1999). God and the victim: Theological reflections on evil, victimization, justice, and forgiveness, Grand Rapids, MI: W.B. Eerdmans.

Magdalene, F. R. (2014). Trying the Crime of Abuse of Royal Authority in the Divine Courtroom and the Incident of Naboth's Vineyard, In Mermelstein, Ari; Holtz, Shalom E. (Eds.). The divine courtroom in comparative perspective (pp. 167-245). Leiden Boston: Brill.

Na'aman, N. (2008). Naboth's vineyard and the foundation of Jezreel, Journal for the Study of the Old Testament, 33(2), 197-218.

Nicolaides, A. (2010). The Laos tou Theou - an orthodox view of the "people of God", HTS Teologiese Studies/Theological Studies, $66(1)$.

Nicolaides, A. \& van der Bank, C.M. (2011). The role of Law as identified in the Old Testament and its impact on the Hospitality Industry, African Journal of Hospitality, Tourism and Leisure, 1(3).

Nkwinti, G. (2013). Rural Development and Land Reform, The New Age Newspaper, February 24,

Oelofse, J. (2014). White EFF member gives land to rightful owners. [Available online at http://www.news24.com/SouthAfrica/Politics/White-EFF-member-Give-land-torightful-owners-20140905]

Pani, G. SJ (2018). The Tyrannical King and Poor Naboth: A never-ending story, La Civilta Cattolica, [Available online at https://www.laciviltacattolica.com/the-tyrannical-king-and-poor-naboth-a-never-ending-story/]

Raven, J. H. (1979). The History of the Religion of Israel, Grand Rapids, MI: Baker Book House.

Rofé, A. (1988). The Vineyard of Naboth: The Origin and Message of the Story, Vetus Testamentum, 38(1), 89 -104.

Russell, S. C. (2014). Ideologies of Attachment in the Story of Naboth's Vineyard, Biblical Theology Bulletin: Journal of Bible and Culture, 44(1), 29-39.

Russell, S. C. (2016). Space, Land, Territory, and the Study of the Bible, Brill Research Perspectives in Biblical Interpretation, Brill, 1(4), 1-64.

Scheffler, E. (2017). ROYAL CARE FOR THE POOR IN ISRAEL'S FIRST HISTORY: THE ROYAL LAW DEUTERONOMIAN 17:14-20), HANNAH'S SONG (1 SAMUEL 2:1-10), SAMUEL'S WARNING (1 SAMUEL 8:10-18), DAVID'S ATTITUDE (2 SAMUEL 24:10-24) AND AHAB AND NABOTH (1 KINGS 21) IN INTERTEXT, Scriptura: Journal for Biblical, Theological and Contextual Hermeneutics, 116(2), 160-174.

Vandagriff, M. (2019). A modern rendering of Naboth's vineyard, Review and Expositor, 116(1), 38-41. DOI: $10.1177 / 0034637319830083$

Yafé, F. C. (1989). The case of Naboth's vineyard (1 Kings 21): An historical, sociological and literary study (PhD dissertation), The Jewish Theological Seminary of America. 